\title{
в) Туберкулез.
}

183. Туберкулезный энтеройолит. F. S m it h i es (Am. Mell. J., 22/XII, 1928), разбирая материал Чикагского туберк. санатория на 1000 коек, сообщает, что 40\% всех легочных туб. б.б. имели диспептические явлендя. Всесторонне обследовав 80 б.б. с выраженными явлениями легочпого тубернулеза и түо̆. энтероколита, а. делит все случаи туб. энт. иа 3 группы: легкие, средние, тянелые. В первой трупше: при выраженных легочных явленяя, громе незначительных диспептически лвлений и локализированной боли в прав. нижнсм квадранте жипота, ничего клиниески не обнаруживалосн, 2-л гр.: обычно при резком ухудшенпи легочного процесса повляются кишечные расстройства п остагтся упорными: запор, диррея, боли, язвенный стул, дегидратация, утолщение стеног coeci, colonis; рентген дает дефорпацию конечной части ilei, coeci, colonis. 3-я гр.: тяжелые жлучаи легочного tbe с множеств. язвами отдельными или сливаюпимпся, прондзываюцим все слои гипечной стенки, обычно сморть от геморрагй, перфораций и истощения. А. саштает рентгеностошию пеобходимым нетодом исследования даже в первой группе. Основной локализацией туб. әнтероколита являются аррепdix, coecum, colon asc. Указывая на paботы A r ch ibald'a (Canad. M. A. I). автор, как основной метод лечения, рекомендует хирургическое вмепательстьо (лапаротомию) с иссечением строго локализрованных түберлулезных пораженпй типечника.

H. ITpanos.

184. Ннтрадерлальная вакиинаиия BCG. A. W a $11 \mathrm{~g}$ r e ri, (Am. Med. J. 15/XII 1928), указывая на отсутствие достаточного количестна данных об имиуниздругцем действи ВCG, вводимх рег os (по Calmetty ipoбa c туберкулином в этих случаях ноложительной бывает редко) и желая псследовать нлинчески течение вакцинаци, шредлагает введение BCG не per os, a in т т р адерма ль н о. А. отбирал детей пред инокульцией, производя внутригожные пробы 0,1 до $3 \mathrm{mg}$ 0. T., так как пробу P i r u e t a. считает недостаточной. Если ребевок не реагировал на эту внутрикожную пробу, то считался годным для вакиинации ВCG. На месте инъекции $0,25-1 \mathrm{mg}$ ВС̈ появлялся узелок, державпиися носколько дней и исчезавший; несголько недель спустя поялялась инбильтрация, увеличивавпаяся в объеме, через нагноение пропсходила перфораця ситіs и фистула самостолтельно излечичалась. В 5 случаях а. громе того видел припухание с нагноением и фистулой регионарных лимфатич. желез, в гное были обнаружены BCG латогенные для морских свинок.-Этот факт нагносния лим. железы опровергает взгляд на то, что ВСG не производят никаних анатомических щзменений в железах, т. е. НСG более вирулснтны, чем предполагалось. Фпстула закрывалась втечение нескольих месяцев фиорозным рубцом; желая пзбежать образования фистулы и получить положит. реаццию на туб́ериялин, а. уменьшил дозу BCG до $0,1 \mathrm{mg}$., кағовую доозу он считает оптимальной для интракутанной вакц. Результаты вакцшнаци а. проверял туберкулиновой пробой в $1 \mathrm{mg}$, причем появение аллергии варьировалось от $1^{1 / 2}$ до 16 недель в завислмости от дозы BCG. Появление чувствительности к туберкулину после ВСG говорит о том, что ребенок вакцинрован-это единственный метод проверки вакцинирования, и это поддерживает теорию о том, что только те дети действительно иммунны, готорые дают чувствительность к түберпулину после вакцинации. У детей, не пиевпих аллергии, через 6-7 недель производилась ревакцинация BCG, иногда сопровождавшаяся не только появлением чувствптельности п туберкулин, но п нагноением первичвого, не давпего аллерги места укола-узелка.

Отмечал далее пндивидуальные реации на ВСG и разлиную вирулентность различных предаратов ВCG, а. говорит, что только при интрадернальном методе можно видеть и следить за результами вакцинци, чего нельзя сделать при введении ВСG per os.

H. Kра.noв.

\section{2) Внутренние болезни.}

185. Hсруиение проводимости предсердия. W. D r es s l e r (Mediz. Klin. גi̊ 5-1929) приводит два случая наблюдавпихся им нарупений в атрио-вентрижулярной проводяпей системе, при которых в одном әлектрогардтограмма дала положительную волну „Р“ при атрио-вентрикулярных әкстрасвстолах, а в другом

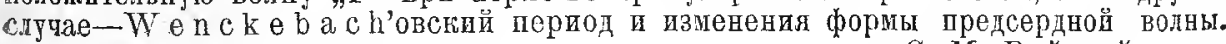
C. М. Райский. 